\title{
3 Railway works bands, choirs and 3 musical societies
}

\section{Railway brass bands}

Railways and brass bands have long been associated. The first association, and one familiar to many, is the long tradition of brass bands playing at railway stations to mark significant occasions, arrivals and departures. This started in the nineteenth-century when it became customary to play Handel's 'See the conquering hero comes' to celebrate the opening of a line or station, bands also often accompanied early railway excursions. By the end of the nineteenth century there were more than 7000 brass bands in the $\mathrm{UK}^{1}$ and audiences for open-air concerts and contests were measured in the tens of thousands. ${ }^{2}$ Without the railways this would not have been possible: the bands and their considerable fan base would not have been able to get to the national championships, which were often some distance away. They were also events which some players considered to be the raison d'etre of the movement. This is not the only association between the bands and the railways. The Victorian establishment 'held music and, in particular, art music to be a force for moral and positive good among working people. ${ }^{3}$ and, from the early days of the movement, brass bands were often linked to a work force. So too were choirs and, to a lesser extent, orchestras and bell ringers.

In 1847 The Musical Times wrote of the Great Western Railway (Swindon) Band

In the large workshops of the Great Western Railway, at Swindon, a number of these men have combined to make a most excellent orchestra, seconded by the liberality and encouragement which seems to pervade the Company's arrangement at this village, for the benefit, improvement and amusement of their workmen. 
The brass band movement was particularly strong in the North of England, bands were often linked to workplaces including railway companies and works. The largest category is that of the colliery bands followed by those related to the railways. ${ }^{4}$ Two such bands were the Leeds Railway Foundry Band and the Doncaster Loco Band. Their stories tell us much about both nineteenthcentury brass bands and railway history.

\section{The Leeds Railway Foundry Band}

The Railway Foundry was a railway engineering workshop in the Hunslet area of Leeds. It was established in 1838 by Shepherd and Todd. Orders were soon received from the Liverpool and Manchester Railway, the Leeds and Selby Railway, Hudson's York and North Midland along with a couple of locomotives which were exported to the Paris \& Orleans Railway. In 1844 there were 40 members of staff, by 1847 there were 400 . This was the year that the company produced their most famous engine, the Jenny Lind. It was built for the London, Brighton and South Coast Railway and became the basis of one of the company's most successful standard designs. By now 'railway mania' was in full swing and the Railway Foundry's use of standard designs meant that new engines could be bought off the shelf. Many engines were based on the Jenny Lind and these were exported all over the world. In 1858 the Leeds Foundry had produced over 600 engines and by 1860 it had become the biggest railway workshop in the world. It went on to build engines for around another 100 years.

The Leeds Railway Foundry Band started its life in 1851 as the Fairbairn's Wellington Saxhorn band but soon changed its name when it became attached to the foundry. ${ }^{5}$ The 1850 s was a significant period in the development of brass bands. The bands' means of funding fell largely into three types: the first was those, such as the Leeds Railway Foundry band, who were linked to a single workplace or were the beneficiaries of wealthy patronage; the second type was subscription bands who relied for their support from the wider community such as mechanics institutes or temperance societies or indeed the members themselves. ${ }^{6}$ The third type belonged to the burgeoning 1859 volunteer movement. Many works bands were also partly funded by subscriptions. The thinking behind such industrial patronage stemmed from Victorian paternalistic ideology in the belief that it helped to 'improve' the workers. ${ }^{7}$ There 
were further advantages for bands that were linked to a workplace: membership gave improved job security; as time went on, it became common for outstanding players to hold retainers for their services; and there was more flexibility to allow players to miss work to perform in concerts and contests. Works bands also provided entertainment for their fellow workers. The repertoire was very largely arrangements of operatic works and soon thousands of people were introduced to art music through the brass band. At the same time winning contests became a matter of local pride and importance for the workforce.

The first large-scale brass band contest took place at Belle Vue, Manchester in 1853. For many years (1836-1970), there was a zoo and amusement park at Belle Vue Zoological Gardens as well as an annual circus: it was also a popular destination for excursions in the early days of the railways. The first excursion train to Belle Vue ran on the Manchester and Birmingham railway - from Macclesfield to Longsight station. The growing rail network and the provision of cheap excursion fares soon meant that contests became the setting for bandsmen drawn from wide geographical areas. Although only eight bands took part in the first contest, The Manchester Guardian estimated that there were 16,000 people in attendance and rather snootily reported that

...all the bands, without exception chose selections from operas and concerted pieces, the majority of which were intricate and difficult of execution indeed such as might have taxed the highest powers of professional performers. And when it is considered that all the members, without exception, (although upwards of one hundred), belonged to the working classes, and studied music, not professionally but for recreation, the performances were in the highest degree creditable both to their taste and proficiency. ${ }^{8}$

Although the Leeds Railway Foundry Band did not take part in the first Belle Vue contest they did enter the second one in September 1854 and went on to win the first prize of $£ 20$. The contest attracted 14 bands, with 191 performers in all, and an even larger audience of 20,000. Most of the spectators were brought by special trains from West Yorkshire, East Lancashire and Staffordshire. Some of the audience would have been Belle Vue's normal pleasure seekers but the Manchester Guardian reported that a large proportion of those present were there for the music, 'proud of the efficiency of the bands from their respective localities'. The report continues, 
All the bands were what are called country bands, consisting, not of professional musicians, whose whole time is devoted to the study and practice of the art, but of hard working artisans, who have found its almost unaided study and practice an intellectual and elevating pursuit during the intervals between labour and repose.

The Leeds Railway Foundry was conducted by Richard Smith (1820-1890) who became an important figure in the early Belle Vue contests. Smith acted as both leader and conductor of the band which meant that as well as conducting he played the solo cornet part, a practice common at the time and not given up until near the end of the century. In addition to the cash prize won by the band, Smith received a bombardon worth 10 guineas. ${ }^{9}$ The award of special prizes of instruments was to become an important feature of major contests when bands were always in needed of more, often expensive instruments. Following the announcement of the results the winning band returned to the platform and played Handel's 'See the conquering hero comes'. A year later Richard Smith took second place with the same band, and in 1856 he took the top two places: Leeds Railway Foundry came first and Leeds (Smith's) came second. It seems that this was a controversial decision. Shortly after the contest, members of Leeds (Smith's) band complained bitterly of this decision and put up a 'Musical Challenge for $£ 100$ ' to the Railway Foundry Band. They wrote:

The decision at the recent contest at Manchester, certainly struck every one who heard the bands play on that occasion as the most barefaced and ridiculous ever sent out to the public; and that gentlemen possessing the situations and standing the judges are supposed to have, could be hoodwinked to give it, excited the disgust of the public, amateurs, and musicians assembled on the occasion, who received it with mingled hisses, cheers, and groans...WE HEREBY CHALLENGE THE RAILWAY FOUNDRY BAND, who received the Prize Instrument, to play for a purse of equal stakes of $£ 50, £ 100$ or any higher sum, either band to and as they now stand, the leaders singly, or instrument against instrument singly, in one week from this date, the money to be staked in the hands of some disinterested and respectable party; and thus expose one of the worst pieces of jugglery and imposition ever practised on the public at a pretended brass band contest; the greatest part of the persons assembled declaring that they (Railway Foundry Band) played the worst but one on the occasion. We have received offers from other bands, and from private individuals, to back up to any amount and expressive of their disapprobation, and believe that it was all agreed before the contest took place in consideration of CERTAIN WEIGHTY MATTERS, which no doubt will be brought to light afterwards. 
An immediate reply, addressed to Smith's Leeds Brass Band, 65, Stamford Street, Leeds, will have prompt attention. From the Members of SMITH'S LEEDS BRASS BAND.

In the six years from 1853 to 1858,34 different bands competed at Belle Vue, seven of which were works bands, four of these railway bands - as well as the Leeds Railway Foundry band were foundry bands from Bradford, Doncaster, and Tidswell's Foundry Band (Leeds). As can be seen, all these bands were from Yorkshire 'confirming the domination of that county at that time'.

\section{The Doncaster Loco Band}

The Great Northern Railway established the Doncaster Locomotive and Carriage Building Works in the early 1850s, a plant works which later became famous for building the LNER locomotives Mallard and the Flying Scotsman, as well as many thousands more locomotives.

The Doncaster Loco Band formed in June 1852, £50 having been spent on instruments. The band did not have a regular bandmaster or musical director and it was short lived. However, in 1856 a new band was formed: the Doncaster Plant Works Band (sometimes known as the Great Northern Railway Plant Works Band). George Birkinshaw, the father of the celebrated nineteenthcentury Black Dyke cornet player of the same name, was the conductor. Its instrumentation included several brass instruments which had been popular in the early days of brass bands - six cornopeans, two ophicleides, and an Eb bass bombardon - but were mostly dropped in the 1860s and replaced by more modern instruments. ${ }^{10}$ The band won several prizes between 1859 and 1861. In September 1859 they won the first prize of $£ 15$ at Peterborough here the bandsmen had to 'defend themselves physically against disappointed rivals afterwards'. They were renamed the Doncaster Volunteer Band in 1859, giving many outdoor concerts in the town often playing arrangements of marches, polkas, gallops, quadrilles and waltzes composed or arranged by their conductor Birkinshaw. The works band lasted until around 1910 and was followed by Doncaster National Union Railway Band which was active around the late 1920s and early 1930s. ${ }^{11}$ 


\section{The Crystal Palace National Brass Band Contest and the role of the railways}

One of the first national brass band championships took place at Crystal Palace in 1860. After the Great Exhibition in 1851, which had attracted thousands of visitors many on special excursion trains, the re-constructed Crystal Palace opened in 1854 in the South London suburbs in a newly enlarged form. Two stations were needed, both were originally at the ends of branch lines and exceptionally large for a South London suburb. One is now defunct. The former railway engineer George Grove was the company secretary and he wished to host orchestral concerts and oratorio festivals. These were highly successful, Grove wrote the programme notes, eventually retiring from his Crystal Palace post to work for the publishers MacMillan where he edited the famous Grove Dictionary of Music and Musicians.

The Crystal Palace National Brass Band Contest was organised by Enderby Jackson, a talented musician and entrepreneur from Hull. In collaboration with railway companies, Jackson secured inexpensive railway day excursions for bandsmen and their supporters...from the north to the contest' organising excursion trains that would 'run from all principal towns on the Great Western, Midland, London and North Western, Great Northern, South Western, and other railways'. All bands paid the same ticket prices regardless of the distance they had to travel to Sydenham. ${ }^{12}$ Jackson paid the railway companies up front and then covered his costs with the entry fees the bands had paid. ${ }^{13}$ Posters proclaimed - 


\section{National Brass Band Contest - Crystal Palace, Sydenham CRYSTAL PALACE - GREAT NATIONAL BRASS BAND CONTEST TUESDAY, 10th, and WEDNESDAY, 11th July.}

Arrangements have been made for a GRAND MONSTER BRASS BAND CONTEST on the above days, in which upwards of ONE HUNDRED BANDS from all parts of England are engaged to take part, comprising in all TWO THOUSAND BRASS INSTRUMENT PERFORMERS. Valuable Prizes, in Money and Cups, will be given by the Company; and, in addition, the principal Music's' instrument makers In London have signified their intention to present several first-class instruments as special prizes.

The Contest will commence each day at, Ten o'clock, and on both days the whole of the Bands will meet at Three o'clock precisely in the Handel Orchestra, and perform

Mendelssohn's "Wedding March", Haydn's Chorus, "The Heavens are Telling", Handel's "Hallelujah", "Rule Britannia," and "God Save the queen." A Monster Gong Drum, seven feet in diameter, manufactured expressly for the occasion, will accompany the combined bands.

Admission, Tuesday, Half-a-Crown; Wednesday, One Shilling.

NOTICE.-Excursion Trains will run from all principal towns on the Great Western, Midland, London and North Western, Great Northern, South Western, and other railways; for full particulars of which see the Companies' advertisements and bills.

The Times estimated that on the second day of the 1860 Crystal Palace concert the audience 'being considerably over 22,000, ${ }^{14}$ The 44 bands performed in turn before the appointed judges, on platforms erected in various parts of the building. They each had to play two pieces, one of their own choice plus a set of quadrilles composed by Enderby Jackson. The most popular choices were arrangements of operatic arias by Bellini, Donizetti, Rossini and Verdi. Next they assembled together to play some of the staple pieces of brass band repertoire of the time - 'Rule Britannia,', The Hallelujah Chorus', Mendelssohn's 'Wedding March', Haydn's 'The heavens are telling' from The Creation and finishing the massed performance with 'God save the Queen'. The Times reported

The effect of the combined legions of "blowers" (upwards of 1,200 strong) was tremendous. The organ, which accompanied them, and which on less exceptional occasions is apt to drown everything, was scarcely audible in the midst of the brazen tempest. Nothing less than the new "monster gong-drum," manufactured by Mr. Henry Distin ${ }^{15}$ - to wield the thunder of which required the united efforts of Messrs. Charles Thompson (of the Crystal Palace Band) and Middleditch (of the London Rifle Brigade)-could prevail against 
it. The pieces that pleased the most-perhaps because the best executed-were Mendelssohn's Wedding March and the National Anthem, both of which were unanimously encored. The whole performance was conducted, with wonderful vigour and precision, by Mr. Enderby Jackson, of Hull. ${ }^{16}$

Of a later contest in 1865, the Musical World reported that 'each of the bands is accompanied by the hundreds of admirers from the surrounding country for miles around' with 'an immense influx of excursionists early trains' playing to a huge audience of $60,000,{ }^{17}$ Brass band contests were important partly because they offered material rewards in the form of prize money and instruments, ${ }^{18}$ but also because they acted as the principal forum for the movement. The North soon emerged as the most successful area for bands. ${ }^{19}$ Hence the contests not only engendered a feeling of pride and community exemplifying working class achievement and potential but also led to 'a spectacular rise in performing standards by brass bands, at a pace unequalled at any other time in any other type of music-making. ${ }^{20}$

The number of brass bands increased until the 1890s and then started a slow decline. This decline had steepened by 1914 when many bandsmen signed up to join the armed forces. Numbers recovered on their return but fell again in World War II and from that point on there were significantly fewer bands in comparison with the earlier glory days. One railway band in particular stands out during the inter-war years - the Horwich Railway Mechanics Institute Band. The band formed in 1899 as the Lancashire and Yorkshire Railway Company Band, three years after the opening of the new locomotive works in Horwich. The intention was to recruit from railway employees but only one member of the old Lancashire and Yorkshire Band passed the audition. Consequently other members were recruited from Black Dyke, Irwell Springs and Foden's and in 1915 the band took second place at Belle Vue. After a strike at Foden's motor works, a dozen players who had been pickets were sacked and promptly moved to the Horwich band. The band's greatest achievement was to win the National Championship of Great Britain at Crystal Palace on 23rd September 1922, becoming 'Champions of Great Britain and the Colonies' and receiving the 1000 guineas trophy. The Bolton Journal reported their triumphant return home.

As the time for the bands arrival from London approached, the streets became alive with people, and soon dense crowds had gathered outside the station and 
lined the approach to the platform. It appeared that the whole of Horwich had turned out en-masse to give the champion band a rousing reception...The train...was gaily decorated with bunting and evergreens, and on the front of the engine was the device 'welcome home.' Loud cheers were given, fog signals were exploded on the line, and The Horwich Old Band played a lively air as the train steamed into the station. Headed by Horwich Old Band, and loco workers carrying torch lights, the band drove in a charabanc passing cheering spectators. .. cries of 'Bravo Horwich' could be heard above the din. ${ }^{21}$

It is difficult to make an accurate count of the number of railway works bands, partly because of the their transitory nature and changing names, but the brass band researcher Gavin Holman in The works brass band - a bistorical directory has included the following bands connected to railway companies, locomotive works, the National Union of Railwaymen and railway foundries. ${ }^{22}$ The following list does not claim to be comprehensive, but it provides a useful overview of the number of bands connected in some way to the railways. 


\section{0 railway brass bands}

\begin{tabular}{|c|c|}
\hline BAND NAME & DATES ACTIVE \\
\hline Belfast and Northern Counties Railway Brass Band & Active in 1872 \\
\hline Blyth LNER Band - Northumberland & 1921 -late 1950 s \\
\hline \multicolumn{2}{|l|}{ Bradford Railway Foundry Band } \\
\hline Bristol and District NUR Band & $1920 \mathrm{~s}-1930 \mathrm{~s}$ \\
\hline Cambridge Railway Band. & 1920s - 1930s. \\
\hline CardiffGWR Workers Band & $1901-1930$ s \\
\hline Cricklewood Midland Locomotive Brass Band & $1890 \mathrm{~s}$ \\
\hline $\begin{array}{l}\text { Crewe Locomotive Steam Works Band, sometimes known as the } \\
\text { Crewe Steam Sheds Band. Its leader was manager of the steam sheds } \\
\text { at the railway works. }\end{array}$ & $1863-1930 s$ \\
\hline \multicolumn{2}{|l|}{ Darlington LNER Band } \\
\hline Doncaster Railway Foundry Band & $1850 \mathrm{~s}-1860 \mathrm{~s}$ \\
\hline $\begin{array}{l}\text { Dubs Loco Works Brass Band - Glasgow. Dubs and Company was } \\
\text { a locomotive works founded in } 1863 . \text { In } 1903 \text { it became part of the } \\
\text { North British Locomotive Company which built 4,485 locomotives. }\end{array}$ & $1900-1906$ \\
\hline \multicolumn{2}{|l|}{ Edlington NUR Brass Band - Doncaster, Yorkshire } \\
\hline $\begin{array}{l}\text { Epping Town Band Founded by a Great Eastern Railway engine } \\
\text { driver. Many original bandsmen were railway workers and the first } \\
\text { bandmaster another railway worker. }\end{array}$ & 1894 - early 1920 s \\
\hline Gateshead LNER Band & Active in 1932 \\
\hline $\begin{array}{l}\text { Glasgow Loco Works Band Also known as North British } \\
\text { Locomotive Company Band }\end{array}$ & $1900 \mathrm{~S}-1920 s$ \\
\hline $\begin{array}{l}\text { Gorton Foundry Band Based at Beyer Peacock Ltd manufacturer } \\
\text { of locomotive engines. Around 8,000 engines were built there } \\
\text { between } 1855 \text { and } 1966 .\end{array}$ & $1880 \mathrm{~s}$ \\
\hline Great Eastern Brass Band - Bristol & $1870 \mathrm{~s}-1880 \mathrm{~s}$ \\
\hline GER Band - Ipswich, Suffolk & $1860 \mathrm{~s}$ \\
\hline GER Works Band - Stratford, Essex & Late $1850 \mathrm{~s}-1920 \mathrm{~s}$ \\
\hline GWR and Metropolitan Band - London & 1950s \\
\hline GWR (Swindon) Band - Wiltshire & $1847-1900 \mathrm{~s}$ \\
\hline $\begin{array}{l}\text { Great Western Paddington Brass Band Also known as Great } \\
\text { Western Railway Carriage Works Brass Band }\end{array}$ & $\begin{array}{l}\text { Active in } 1856 \text { and } \\
1865\end{array}$ \\
\hline GWR Brass Band - Worcester & Active in 1888 \\
\hline GWR Employees Brass Band - Taunton, Somerset & Active in 1895 \\
\hline GWR Social, Education and Union Association Band - Wiltshire & $1918-1947$ \\
\hline Hastings Southern Railway Band - Sussex & Active in 1928 \\
\hline
\end{tabular}




\begin{tabular}{|c|c|}
\hline $\begin{array}{l}\text { Hawthorn's Locomotive Works Brass Band - Newcastle upon } \\
\text { Tyne. R.W. Hawthorn \& Co's Locomotive works. }\end{array}$ & Active in 1867 \\
\hline $\begin{array}{l}\text { Horwich Lancashire and Yorkshire Railway Company Band } \\
\text { Formed three years after the opening of the new locomotive works. }\end{array}$ & $1889-1830$ \\
\hline \multicolumn{2}{|l|}{ Leeds Railway Foundry Band } \\
\hline Manchester and Sheffield Railway Company Locomotive Band & $1860 \mathrm{~s}$ \\
\hline $\begin{array}{l}\text { Midland Railway Loco Works Band Also known as St Pancras } \\
\text { Midland Railway Band. }\end{array}$ & 1890 s and $1900 \mathrm{~s}$ \\
\hline $\begin{array}{l}\text { Newton Abbot Locomotive Brass Band South Devon } \\
\text { Locomotive Works. }\end{array}$ & $1855-1863$ \\
\hline Newcastle LNER Band - Northumberland & 1930s \\
\hline \multicolumn{2}{|l|}{$\begin{array}{l}\text { New Cross Locomotive Band Had several names including } \\
\text { New Cross Railway Mission Brass Band. }\end{array}$} \\
\hline $\begin{array}{l}\text { London, Brighton and South Coast Railway Locomotive } \\
\text { Department Brass Band - New Cross }\end{array}$ & $1890 \mathrm{~s}$ and $1900 \mathrm{~s}$ \\
\hline New Holland NUR Silver Band - Lincolnshire & 1890s-1920s. \\
\hline Newton Heath Loco Works Band - Lancashire & $1950 \mathrm{~s}$ \\
\hline $\begin{array}{l}\text { Newcastle Locomotive Works Band Also known as Stephenson's } \\
\text { Operatic Brass Band. Based at the Robert Stephenson \& Co. } \\
\text { Locomotive works. }\end{array}$ & $\begin{array}{l}\text { Early } 1860 \text { s - mid- } \\
1870 \text { s }\end{array}$ \\
\hline \multicolumn{2}{|l|}{ North Staffordshire Railway Locomotive Band } \\
\hline Rotherham Locomotive Brass Band & Active in 1868 \\
\hline Reading Foundry Brass Band Great Western Railway Foundry & $\begin{array}{l}1860 \text { still active in } \\
1875\end{array}$ \\
\hline Reading NUR Band & Active in 1921 \\
\hline Peterborough Great Northern Railway Locomotive Brass Band & 1857 - early 1860 s \\
\hline $\begin{array}{l}\text { Sheaf Works Prize Band - Lincoln, associated with Ruston, Proctor } \\
\& \text { Co. factory which produced locomotives and steam shovels. }\end{array}$ & 1890 s to the $1920 \mathrm{~s}$ \\
\hline $\begin{array}{l}\text { South Devon Locomotive Works Brass Band - Newton Abbot. } \\
\text { South Devon Locomotive Works. }\end{array}$ & $\begin{array}{l}1855, \text { still active in } \\
1863\end{array}$ \\
\hline \multicolumn{2}{|l|}{ Southern Railway Works Brass Band - Lancing, Sussex } \\
\hline $\begin{array}{l}\text { Swindon British Railways Social and Educational Union } \\
\text { Silver Band }\end{array}$ & 1948 \\
\hline \multicolumn{2}{|l|}{ Tidswell's Foundry Band } \\
\hline Willesden Junction LMS Railway Steam Shed (Silver) Prize Band & Active in 1907 \\
\hline $\begin{array}{l}\text { Wolverhampton Railway Works Band also known as the GWR } \\
\text { Institute Band. The GWR Institute - Stafford Road Railway Works. }\end{array}$ & $1858-1970 s$ \\
\hline
\end{tabular}

\section{Abbreviations}

GER - Great Eastern Railway

LMS - London, Midland and Scottish Railway

GWR - Great Western Railway

LNER - London and North Eastern Railway 
NUR - National Union of Railwaymen

\section{Railway choirs and musical societies}

From the first half of the nineteenth century large choirs were established throughout the country, by 1860 there existed a Great Northern Railway Glee and Madrigal Society based at King's Cross, and towards the end of the century, male voice choirs started to become fashionable. Some of the factors which had led to the rapid increase in the number of brass bands in the nineteenth century - the industrial revolution, Victorian paternalism and philanthropy, an increase in leisure time and an appetite for public entertainment - also led to the huge expansion in the number of choirs and choral societies. At the same time music festivals sprang up all over the country and the railways played a large part in their success.

The choral movement shared the same competitive element as the brass band movement. The British Federation of Musical Competition Festivals was formed in the early 1920s and again the railways helped to facilitate the competitions. The Federation negotiated Special Railway Vouchers with the Railway Clearing House enabling choirs to travel reasonably cheaply. Some choirs were accommodated in special excursion trains. In December 1922 Mexborough and Swinton (Yorkshire) Railwaymen's Male Voice Choir organized its first competition, with an entry of twelve choirs. For the large number of choral societies, oratorios, particularly Handel's Messiah, were part of the stable repertoire. A common feature of such festivals was a massed performance on the final day and in 1857 at one of the most famous, the Crystal Palace triennial Handel Festival, Messiah was performed with an orchestra of 500 and a chorus of 2,000 .

In the early twentieth century many of the railway choirs came under the auspices of Railway Musical Societies.

\section{The Great Eastern Railway Musical Society}

The Great Eastern Railway Musical Society was created in 1908. It comprised an orchestra and choir whose members were drawn entirely from railway staff. William Johnson Galloway, a director of the Great Eastern Railway 
Company, was largely responsible for its creation and sometimes took part himself as the conductor. Their performances were of a high standard, enough to attract guest conductors of a high calibre such as Sir Henry Wood and Sir Alexander Mackenzie and to have compositions written for them, for example Men on the Line, a cantata for men's voices by Hubert Bath, composer of the more well-known Cornish Rhapsody.

Several of their concerts took place in the Hamilton Hall, Abercorn Rooms of the Liverpool Street Hotel. Many of these concerts were described as 'smoking concerts', informal concerts where audiences were grouped around tables, refreshments were served between the items and the audience were free to smoke, along with, at times, the performers themselves. Smoking concerts first became popular towards the end of the nineteenth century, as described in The Musical Times of February 1882:

The recent establishment of Smoking Concerts in the metropolis is scarcely so much a proof of the advance of smoking as of the advance of music. The fact is that many persons accustomed to enjoy a cigar or pipe in the evening, and also exceedingly fond of listening to the performance of good works, have begun to see that the gratification of the one desire need not interfere with the occasional gratification of the other, and the result is the growth of the entertainments at one of which a few evenings ago we 'assisted'. Of course with a full orchestra, and a programme containing some of the best of our standard compositions, not only the total absence of ladies, but the arrangement of tables intermingled with seats, appeared strange to one accustomed to attend evening concerts at St. James's Hall; but then the stiffness inseparable from fashionable assemblies was replaced by an air of luxurious enjoyment which appeared thoroughly in consonance with the feelings of the audience: and when the performance commenced the few who desired to converse were effectually hushed by the frowning looks of the musical majority. We can confidently affirm that the characteristic feature of the concert was faithfully preserved, for not only the audience smoked, but the Conductor, the stringed instrument players, and the performers upon wind instruments too when they could get a chance. It was remarked by many that Beethoven sounded much better when, instead of sitting between two elegantly dressed ladies in a sofa stall, you could recline at your ease, a and combine the aroma of the music with the fragrance of the weed. ${ }^{23}$

Performances were not limited to Hamilton Hall, the musicians would travel to venues such as Queen's Hall and to cities outside London including 
York and Edinburgh. The Science Museum holds a collection of concert programmes which include details of concerts given to HM Forces in the YMCA Hall, White City (1915), delegates to the International Railway Congress (1925) and a commemoration concert to mark the retirement of a Works Manager (1932). ${ }^{24}$

In 1923 Great Eastern Railway was grouped with other railways to form the London \& North Eastern Railway (LNER). Consequently the society's name changed to the London \& North Eastern Musical Society in 1924.

\section{The London and North Eastern Railway Musical Society}

The LNER covered Eastern England and Scotland and during the 1930s it had several male voice choirs scattered throughout this area based at Doncaster, Peterborough, Selby and elsewhere. The Doncaster LNER Musical Society had an orchestra as well as a male voice choir. This was the idea of their conductor H A Bennett who directed them in the late 1920s when he was organist at Doncaster Parish Church. ${ }^{25}$ Each year the societies combined for a performance in London under their musical director the English choral conductor Leslie Woodgate (1900-1961). Woodgate joined the BBC in the 1920s and in 1934 he was appointed the BBC Chorus Master. He became one of the foremost choral trainers in the country: for several years he conducted Huddersfield Choral Society and he appeared at the Henry Wood Proms in 1946 conducting the BBC Singers. Woodgate composed music for the LNER, as did Stanley Marchant (1883-1949) organist at St Paul's Cathedral, and railwayman C F Chudleigh Candish, who wrote the popular Song of the Jolly Roger for male voices. ${ }^{26}$

There was a gradual decline in the number of bands between 1895 and 1914, numbers recovered slightly after World War 1 when soldiers returned and communities started to rebuild. The number of bands fell again after World War II but did not recover in the same way. ${ }^{27}$

At the time of writing few bands and choirs with railway connections remain. 


\section{0 current railway brass bands}

\begin{tabular}{|c|c|}
\hline BAND NAME & DATES ACTIVE \\
\hline $\begin{array}{l}\text { York Railway Institute Band Formed by merger of the York City } \\
\text { Brass Band and the Ebor Excelsior Silver Band. York Railway } \\
\text { Institute Golden Rail Band. }\end{array}$ & Founded in 1952 \\
\hline $\begin{array}{l}\text { City of Exeter Railway Band Former names: Exeter \& District } \\
\text { Southern Railways Band, Exeter British Railways (Southern } \\
\text { Region) Band, Exeter British Rail Band. }\end{array}$ & Founded in 1945 \\
\hline $\begin{array}{l}\text { March Brass } 2000 \text { (Cambridgeshire) Former names: March } \\
\text { Railway Servants Brass Band, GER Brass Band, March Railway } \\
\text { Silver Band. }\end{array}$ & Founded in 1891 \\
\hline $\begin{array}{l}\text { Netherfield Railway Band (Nottinghamshire) In } 1950 \text { was } \\
\text { renamed Carlton Silver Band, then Nottingham City Transport } \\
\text { Band in } 1988 \text {. The band spawned Carlton Brass (a junior section) } \\
\text { which went on to become the current Carlton Brass Band. }\end{array}$ & $\begin{array}{l}\text { Founded in the } \\
1890 \text { s }\end{array}$ \\
\hline $\begin{array}{l}\text { South West Trains Woodfalls Band (Wiltshire) Former names: } \\
\text { Woodfalls Temperance Band, South of England Temperance } \\
\text { Band, Woodfalls Silver Band, SWT Woodfalls Silver Band. }\end{array}$ & Founded in 1874 \\
\hline $\begin{array}{l}\text { Swindon Pegasus Brass (Wiltshire) Former names: Swindon } \\
\text { (Gorse Hill) Brass Band, Great Western Railway Social, } \\
\text { Education and Union Association Band, Swindon Rail Staff } \\
\text { Association Band, British Railways Silver Band (Swindon), } \\
\text { Swindon BR Band, Swindon Concert Band. }\end{array}$ & Founded in 1912 \\
\hline $\begin{array}{l}\text { Tylorstown Brass Band (Glamorgan) Former names: Tylorstown } \\
\text { \& District Silver Band, Tylorstown \& Mardy Colliery Band, } \\
\text { Tylorstown (Valley Lines) Brass Band, Tylorstown Band Arriva } \\
\text { Trains Wales. }\end{array}$ & Founded in 1920 \\
\hline $\begin{array}{l}\text { Watford Band (Hertfordshire) Former names: London and } \\
\text { North Western Railway Band, L\&NW Artizan Staff Brass } \\
\text { Band, Watford Artisan Silver Band, Watford Silver Prize } \\
\text { Band, Watford Silver Prize and British Legion Band, Watford } \\
\text { United Ex-Service Men's Band, Watford Silver Band, Hosier \& } \\
\text { Dickinson Watford Band. }\end{array}$ & Founded in 1895 \\
\hline $\begin{array}{l}\text { Wolverton Town Band (Buckinghamshire) Former names: } \\
\text { Wolverton Town Band, Wolverton British Railway and Town } \\
\text { Silver Band (1951-1989). }\end{array}$ & Founded in 1908 \\
\hline $\begin{array}{l}\text { Tilbury Band (Essex) Former names: Tilbury Railwaymen's } \\
\text { Band, Tilbury Town Silver Prize Band, Tilbury Town Band. }\end{array}$ & Founded in 1919 \\
\hline
\end{tabular}

Finally there is one band that after well over 150 years is alive and well and is still heard by many, playing a weekly concert on the concourse of Paddington station. The Great Western Railway Paddington Band started its life in 1855 
as the Great Western Railway Paddington Station Military Band (brass and woodwind) when it played Christmas music outside the stations master's cottage. It has remained active in some form ever since. In 1910, under the name Great Western Railway and Paddington Borough Prize Silver Band, it took part in the National Brass Band Championships at the Crystal Palace coming 8th out of 15 bands. In the mid-1920s it reverted to its military band format, a format which it remains in today.

\section{Endnotes}

1 Gavin Holman. How Many Brass Bands? - An analysis of the distribution of bands in Britain and Ireland over the last 200 years, 2018.

2 Gavin Holman has identified nearly 20,000 distinct brass bands in the UK between 1800 and the present.

3 Trevor Herbert. Bands: The Brass Band Movement in the 19th and 20th Centuries (Milton Keynes: Open University Press, 1991): 9.

4 Gavin Holman. The works brass band - a historical directory of the industrial and corporate patronage and sponsorship of brass bands. 2020.

5 Saxhorns were a family of brass instruments with valves developed by the Paris inventor of the saxophone - Adolphe Sax. Their popularity was short lived, but some saxhorn instruments live on in brass bands being similar to tenor horns, baritones and euphoniums.

6 The bandsmen of Epping Town Band, for example, each paid an entry fee of one shilling and subscriptions of threepence a week towards purchase of music. Money earned by the band was either divided among the bandsmen or put towards uniform purchase.

7 Herbert, Bands, 23.

8 The Manchester Guardian, September 10, 1853.

9 A bombardon is a bass instrument with valves, similar to a tuba and popular during this period.

10 Ophicleides were later replaced by valve basses and contrabasses, for example.

11 Gavin Holman. Brass bands of the British Isles - a historical directory. 2018.

12 Trevor Herbert and Arnold Myers. "Music for the multitude: accounts of brass bands entering Enderby Jackson's Crystal Palace contests in the 1860s. "Early Music 38, no. 4 (2010): 572-84.

13 Ibid

14 The Times, July 12, 1860.

15 Henry Distin (1819 - 1903) was a cornet player and brass instrument manufacturer; born in England but working in America. He improved the design of brass valve instruments and took out several patents on new percussion instruments.

16 The Times, July 11, 1860.

17 Stephen Etheridge. "Southern Pennine Brass Bands and the Creation of Northern Identity c. 1840-1914: Musical Constructions of Space, Place And Region.” Northern History 54, no. 2 (2017): 250.

18 Herbert, Bands, 37.

19 Etheridge, "Southern Pennine Brass Bands", 246. 
20 Herbert, Bands, 7.

21 Stephen Etheridge. Brass Band Contests and Railway Travel: Mobility, Audience Support and Sporting Comparisons. 2017 https://bandsupper.wordpress.com/author/gtrombone/

22 Gavin Holman. The works brass band - a historical directory of the industrial and corporate patronage and sponsorship of brass bands. 2020.

23 The Musical Times, February, 1882.

24 https://collection.sciencemuseumgroup.org.uk/people/ap233/london-north-eastern-musical-society

25 Philip Scowcroft. "Railways in Music". http://www.musicweb-international.com/railways_in_ music

26 Ibid.

27 Holman, How many brass bands? 2018 
10.5920/railways. 3 